\title{
FORCIBLE AND STATUTORY RAPE: AN EXPLORATION OF THE OPERATION AND OBJECTIVES OF THE CONSENT STANDARD
}

RAPE consists of sexual intercourse ${ }^{1}$ with a woman ${ }^{2}$ without her consent. ${ }^{3}$ The crime covers factual situations ranging from brutal attaclis familiar

1. Any penetration, however slight, constitutes sexual intercourse. E.g., NEv. Co:ns. Laws $\$ 10125$ (1929) ; 21 OKLA. STAT. ANN. $\$ 1113$ (1937); S.D. CONE $\$ 13.2802$ (1939); Utar Code ANn. \$103-51-17 (1943); Wash. Rev. Star. $\$ 2437$ (Rem. 1932); Lee v. State 197 Ga. 123, 28 S.E.2d 465 (1943); State v. Coffmann, 360 MIo. 782, 230 S.W.2d 761 (1950). Proof of ejaculation is generally considered unnecessary. E.g., FLs. Srar. ANN. \$794.01 (1944); N.C. GeN. StAt. \$1423 (1943); Tens. Cone Azw. \$10780 (Williams 1934) ; State v. Pollock, 57 Ariz. 415, 114 P.2d 249 (1941) ; Bonner v. State, $206 \mathrm{Ga} .19$, 55 S.E.2d 587 (1949).

Some states have retained the common law conclusive presumption that a by und $r$ 14 years of age is incapable of engaging in sexual intercourse. E.g., State v. Sam, 60 N.C. 300 (1864); Foster v. Commonwealth, 96 Va. 306, 31 S.E. 503 (1893). In most jurisdictions, however, the presumption is rebuttable. E.g., Ansz. Cors A::z. $\$ 43-1401$ (1939) ; Cas. Penal Code $\$ 262$ (Deering 1949); Inaho Cods $\$ 18-6102$ (1918); N.Y. Penal Law \$2012 (Mickinney 1944).

2. Statutes often preclude the possibility of a man raping his wife. E.g., N.Y. PE:int LAw $\$ 2010$ (McKinney 1944); 21 OKLA ST.1T. ANv. $\$ 1111$ (1937). The theory supposedly behind this rule is that when a woman marries, she consents to all asts of sevual intercourse with her husband as long as the marriage exists. Sce Frazier v. State, 43 Tex. Crim. Rep. 142, 86 S.W. 754 (1905). However, a man may be guilty of rape as an accessory when, for example, he procures a man, assists him in the act of rape or forces his wife to submit to another man against her will. People v. Chapman, 62 Mich. 280, 23 N.W. 896 (1886) ; People v. Sfeli, 193 N.Y. Supp. 365 (Sup. Ct. 1922); State v. Dowell, 106 N.C. 722, 11 S.E. 525 (1890); State v. Digman, 121 W.Va 499, 5 S.E.24 113 (1939).

In spite of the fact that most statutes declare that any "person" having sesural connection with a female may be guilty of the crime (c.g., N.J. STAT. A:r:. \$2:163-1 (1939); VA. CoDE $\$ 18-54$ (Michie 1950) ), there is not a single reported case of a woman convicted as principal. This may be explained by the usual construction of the serual act involved as a genital penetration. The assumption that a woman is incapable of perpetrating the act with her own body has been expressed in a few dicta. Sce State v. Flaherty, 128 Mie. 141, 145, 146 Atl. 7, 9 (1929); State v. Williamsan, 22 Utah 243, 249, 62 Pac. 1022,1023 (1900). But a woman may be guilty of rape as an accessory if she helped a man commit the crime. State v. Burns, 82 Conn. 213, 72 At1. 1083 (1909); State v. Pickel, 116 Wash. 600, 200 Pac. 316 (1921).

3. If a woman is legally capable of granting consent, her subjective attitude toward the sexual act determines whether or not it is rape. See text p. $58 \mathrm{infra}$. C $\mathrm{F}$. Pcople v. Harris, 108 Cal. App.2d 84, 238 P.2d 158 (1951) ; People v. Kinne, 25 Cal. App.2d 112, 76 P.2d 714 (1938) ; State v. Marable, 4 Wash.2d 367, 103 P.2d 10S2 (1940). But for an example of the "behavioristic" approach to rape, yypical of many courts at least on the verbal level, see People v. Brown, 138 Cal. App. 748, 33 P.2d 460 (1934).

Statutes may define forcible rape with such phrases as "against her will," or "by force." See, e.g., MAss. Gen. Laws, c. 265, § 22 (1932); ME. Rev. Stat., c 117, $₹ 10$ (1944) ; N.H. REv. LAws, c. $455 \$ 16$ (1942). But these expressions are generdlly considered synonomous with "without her consent." E.g., State v. Flaherty, 123 Ife 141, 143, 146 Atl. 7, 8 (1929); Commonwealth v. Burke, 105 Mass. 376 (1886). 
to tabloid readers to half won arguments of couples in parked cars ${ }^{4}$ or intercourse with willing girls who lack the legal capacity to grant consent. The "facts" may be elusive, ambiguous, or fabricated. And the sexual nature of the crime is conducive to false accusation. ${ }^{\circ}$ Moreover, the word "rape," plus the aspect of a "wronged" girl on the witness stand, may lead to conviction of a defendant, "though never so innocent."

Consent is often an uncertain standard for branding sexual intercourse a crime as serious as forcible rape. Yet the consent standard is required by the important policy goals it now serves. On the other hand, the law's refusal to heed the full consent of young girls, because of an inflexible test of capacity to understand, seems unjustified. Protection of the "pure and naive" should be achieved without punishing many blameless men.

\section{Non-Consent and Its Proof}

\section{Forcible Rape}

Actual physical force exerted against the body of the complaining witness by the defendant to gain sexual access characterizes the most obvious form of rape. ${ }^{9}$ The overt aggression marks the sexual act as rape. Courts also look to the woman's behavior; resistance is a sign of non-consent. ${ }^{10}$ The old rule, now considered obsolete in almost every jurisdiction, required "utmost" resistance by the female until penetration of her organs. ${ }^{11}$ Today, most states hold that the amount of resistance must be proportional to the circumstances

4. Stone v. State, 243 Ala. 605,11 So.2d 386 (1943); Boyd v. Commonwealth, 219 Ky. 62, 292 S.W. 478 (1927); Young v. Commonwealth, 185 Va. 1032, 40 S.E.2d 805 (1947).

5. See note 60 infra.

6. See note 37 infra.

7. Certain words, by themselves, may elicit strong emotional and behaviorial responses. Dollard \& Miller, Personality and Psychotherapy 106 (1950).

8. "[Rape] is an accusation easily to be made and hard to be proved, and harder to be defended by the party accused though never so innocent." 1 HALE, PLEAS of THE Crown 635 (1778). Cf. People v. Scott, 407 Ill. 301, 95 N.E.2d 315 (1950); Selvage v. State, 148 Neb. 409, 27 N.W.2d 636 (1947); Gullat v. State, 80 Okla. Crim. 208, 158 P.2d 353 (1945).

9. People v. Scott, 407 Ill. 301, 95 N.E.2d 315 (1950); People v. Dohring, 59 N.Y. 374, 382 (1874). The statutes commonly define rape as intercourse "by force." E.g., CAI. Penal Cone $\$ 261$ (3) (Deering 1949); Ill. Stat. ANn., 38, $\$ 490$ (Smith-Hurd 1935); Mass. Ann. Laws, c. $265 \S 22$ (1933); N.Y. Penal Law $\S 2010$ (2) (Mckinncy 1944); N.D. Rev. CODE § 12-3001(3) (1943).

10. See Prokop v. State, 148 Neb. 582, 28 N.W.2d 200 (1947); Killingswoth v. State, 154 Tex. Crim. App. 223, 226 S.W.2d 456 (1950); State v. Hoffman, 228 Wis. 235, 280 N.W. 357 (1938). "Force . . must have been such as might reasonably be supposed sufficient to overcome resistance, taking into consideration the relative strength of the parties and other circumstances of the case." 2 Tex. Penal Cone art. 1184 (Vernon 1925).

11. See Thomas v. State, 227 Ind. 42, 83 N.E.2d 788 (1949); Harris v. State, 88 Okla. Crim. 413, 204 P.2d 310 (1949). Contra: Prokop v. State, 148 Neb. 582, 28 N.W.2d 200 (1947). 
of the attack, such as the relative strength of the parties and the futility of persistence. ${ }^{12}$ Other states require only that degree of "good faith" resistance which makes the woman's non-consent reasonably evident. ${ }^{13}$

Although there is no physical struggle between the parties, the legal equivalent may be found in the man's threats to the physical well-being of the woman. ${ }^{14}$ The threats may be verbal or evident from the brandishment of weapons. ${ }^{15}$ The girl must have believed, with cause, that bodily harm would be inflicted upon her if she refused the defendant's sexual demands. ${ }^{10}$ The fact finder then determines whether the circumstances of the act, and the threats alleged to have preceded it, warrant the conclusion that the girl would not otherwise have submitted.17 Many threats other than direct bodily harm, such as loss of a job or suitor, may coerce a girl into submission; and though she may consider herself opposed to the act, the law does not treat these situations as rape. ${ }^{1 \mathrm{~s}}$

Few statutes and fewer cases discuss forcible rape without referring to the behavior of the parties preceding coitus. ${ }^{19}$ Did the defendant beat the girl,

12. E.g., Harris v. State, SS Okla. Crim. 413, 204 P.2d 310 (1949); State v. Thompson, 71 S.D. 319, 24 N.W.2d 10 (1946) ; Lewis v. State, 154 Tes. Crim. Rep. 339, 226 S.W.2d 861 (1950); Jordan v. Commonwealth, 169 Va. \$9, 194 S.E. 719 (1933).

13. E.g., People v. Scott, 407 Ill. 301, 95 N.E.2d 315 (1950) ; People v. Mreyers, 381 IIl. 156, 44 N.E.2d 870 (1942) ; Bulls v. State, 33 Olila. Crim. 64, 241 Pac. 605 (1920). Courts, requiring that resistance "demonstrate" attitude of opposition, are nut clear en whether demonstration must be to fact-finder or accused. The former is probably the better understanding of the rule. See text at note 21 infro.

14. Cal. Pendul Code \$261(4) (Deering 1949); N.D. Rev. Cunz \$12-3001(4) (1943) ; 21 Ofla. Stat. ANa. $\$ 1111$ (5) (1937); 2 Tex. Pemal Conz art. 1185 (Vernon 1925) ; People v. Cassandra, \&3 Cal. App.2d 272, $18 S$ P.2d 546 (1948); People v. Lay, 66 Cal. App.2d 889, 153 P.2d 379, 381 (1944); State v. Thompson, 237 X.C. 19, 40 S.E. 2d 620 (1946). Unlike American jurisdictions, some other countries-U.S.S.R, Switzerland, and Yugoslavia-regard economically coerced coitus as rape. Donnelly, The New Yuggoslav Criminal Code, 61 YaLe L.J. 510, 527 n.119 (1952).

15. E.g., People v. Tollack, 105 Cal. App.2d 169, 233 P.2d 121 (1951); Rider v. State, 195 Ga. 656, 25 S.E.2d 304 (1943). See People v. Harris, 10 S Cal. App.2d \&4, 238 P.2d 158 (1952) ; cf. People v. Flores, 62 Cal. App.2d 700, 145 P.2d 318 (1944).

16. See, e.g., Allison v. State, 204 Ark. 609, 164 S.IW.2d 442 (1942) (woman believed that the man held a gun in his hand when, in fact, he held only a sticl:); People v. Flores, 62 Cal. App.2d 700, 145 P.2d 318 (1944) (woman feared physical harm from circumstances of encounter and deportment of the defendants though no verbal threats or display of weapon). See also Green v. State, 135 Fla. 17, 1S4 So. 504 (1938).

17. For an indication of information courts will admit to determine the cause of the woman's submission, see Deffenbaugh y. State, 32 Ariz. 212, 257 Pac. 27 (1927) (defendant father of the complaining witness, threatened repetition of previous brutal beatings); State v. Marable, 4 Wash.2d 367, 103 P.2d 1082 (1940) (scene of the encounter and perversions supposedly performed on woman). See also People v. Flores, 62 Cal. App.2d 700,145 P.2d 318 (1944).

18. See Donnelly, supra note 14 , at 527 n.119. For a discussion of the legal consequences of threats other than direct bodily harm, see note 75 infra.

19. See notes 13,14,15, and 18 supra. But see So. Car Cone $\S 1109$ (1942). 
to what extent did she fight back, or what did he say or do to put her in fear? These are crucial points in the adjudication of the defendant's guilt. Yet there is much to indicate that behavior is relied on merely as a token of the woman's attitude toward the act. The law of rape does not punish even the most brutal beating of a woman; the only behavior punished by the law of rape is the sexual penetration that follows. Although proof that the defendant used force commands a guilty verdict, the legal conclusion probably assumes that if physical violence was a necessary overture to the act, the woman did not submit willingly. This interpretation is borne out by the elimination of the "utmost resistance" requirement. ${ }^{20}$ The complaining witness is now expected to show only that degree of resistance which one would reasonably expect, under the circumstances, from a woman who did not consent. ${ }^{21}$ The degree of resistance required was reduced without affecting the criminality of the penetration because even lesser resistance may indicate clearly an attitude of nonconsent. Moreover, when a woman stops struggling before the actual penetriktion, courts may explain her cessation of active opposition either by the "fittility of persistence" (in which case the act is rape) ${ }^{22}$ or as a change of attitude in favor of consent (not rape). ${ }^{23}$ Here, the court's impression of the woman's attitude must determine the criminality of the act. And even when there is no physical force or show of opposition, the accused need not utter a verbal threat or display a weapon to incur the rape penalty. If the court believes that the woman would not normally have consented to sexual intercourse under the circumstances, ${ }^{24}$ an "implied threat" or a general "array of force" will be found on which to base a conviction. ${ }^{25}$

For the aid of the fact finder, rules of evidence regulate the admission on the merits of material thought to be relevant indicia of the complaining witness' subjective state of mind. ${ }^{26}$ Objective signs of a physical struggle- such as bruises or scratches on the parties, torn clothing, traces of blood, and screams-are always admissible. ${ }^{27}$ In the absence of any show of violence,

20. See notes 16,17 supra.

21. E.g., Lewis v. State, 154 Tex. Crim. Rep. 329, 226 S.W.2d 861 (1950).

22. E.g., People v. Mummert, 57 Cal. App.2d 849, 135 P.2d 665 (1943); Pcople v. Cook, 10 Cal. App.2d 511, 52 P.2d 538 (1936) ; Ritter v. State, 224 Ind. 426, 67 N.E.2d 530 (1946). See also note 16 supra.

23. E.g., People v. Scott, 407 I1l. 301, 95 N.E.2d 315 (1950); Rogers v. State, 204 Miss. 891, 36 So.2d 155 (1948); Cascio v. State, 147 Neb. 1075, 25 N.W.2d 897 (1947). 24. E.g., State v. Marable, 4 Wash.2d 367, 103 P.2d 1082 (1940).

25. E.g., People v. Kinne, 25 Cal. App.2d 112, 76 P.2d 714 (1938); Davis v. Commonwealth, 186 Va. 936, 45 S.E.2d 167 (1947); People v. Flores, 62 Cal. App.2d 700, 145 P.2d 318 (1944).

26. See, e.g., Mikell v. State, 242 Ala. 298, 5 So.2d 825 (1941); State v. Esposito, 122 Conn. 604, 191 Atl. 341 (1937); State v. Warga, 83 N.F. 532, 145 Atl. 456 (1929),

27. Bulls v. State, 33 Okla. Crim. 64, 241 Pac. 605 (1926); Hart v. State, 139 Tex. Crim. Rep. 101, 138 S.W.2d 818 (1940). Often testimony is offered of a doctor who made an examination of the complaining witness after the act allegedly took place. His findings 
the jury must rely on the circumstances of the encounter, the characters of the parties, and their previous relationship to infer the likelihood that the act was consensual. 28 For example, evidence of the complaining witness' consent to previous acts of coitus with the defendant may be admitted, via the theory of a "continuing state of mind," to prove her consent to the act in question."3 Also, evidence of her general moral character is usually admissible. 00 Courts apparently reason that a reputation of "loose moral character" probably has a basis in fact and that a girl with such a character is more likely than not to consent to sexual intercourse in any given instance. ${ }^{31}$ However, there is conflict over the admissibility of her specific acts of intercourse with others; al-

as to injury to the body and the genital organs of the girl are admissible. Alliord v. State, 31 Ala. App. 62, 12 So.2d 404, cert. doricd, 244 Ala. 145, 12 So.2d 407 (1943); People v. Cox, 383 Ill. 617,50 N.E.2d 758 (1943).

Microscopic examination of the sexual organs, clothing, etc. of the parties may reveal evidence that sexual connection took place between them, or in some cases that it was forcible. Rife, Scicntific Evidente in Rape Cases, 31 J. Cras. L \& Crasrandray 232 (1940).

However, penetration sufficient to constitute "intercourse" may be found without insertion to the point of rupturing the hymen or entrance into the vagina. See, c.g., Lee $v$. State, 197 Ga. 123, 28 S.E.2d 465 (1943) ; State v. Snyder, 199 Wash. 298, 91 P.2d 570 (1939).

For an outspoken view of the gynecologist's role in the discovery of evidence, see Schaufler, The Immature Fenale Genital Tract. 24 J. PErimutares 22), 223-6, (194t).

28. Deffenbaugh v. State, 32 Ariz. 212, 257 Pac. 27 (1927); State v. Dill, 42 Del. 533, 40 A.2d 443 (1945) ; People v. Yannucci, 283 N.Y. 546, 29 N.E.2d 185 (1940). See notes 26 and 27 infra.

If the circumstances of the alleged attack show a marked resemblance to prior attaclis by the defendant upon other women, and the previous events are not "too remote" from the event in issue, the state may introduce evidence of the prior attaclis in order to show "design" to commit the act in question. People v. Cassandras, 83 Cal. App.2d 272, 18S

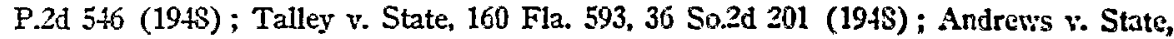
$196 \mathrm{Ga}$ 84, 26 S.E.2d 263, cert. dinied, 320 L.S. 780 (1943). See also State v. Martunsz. 67 Ariz. 389, 198 P.2d 115 (1948); People v. Sullivan, 101 Cal. App.2d 322, 225 P.2d 645 (1950). But, cryptically enough, "it is not permitted to shov in the prisoner a tendency or disposition to commit the crime with which he is charged." State v. Lapage, 57 N.H. 245, 289 (1876), quoted in 2 Wrgarore, Eviderice $\$ 357$ (3d ed. 1940). But ef. State v. Wiswell, 128 Kan. 659, 664, 280 Pac. 780, $7 \$ 2$ (1929) (in a case of forcible rape, unused contraceptives found in the front door pocket of the car in which the alleged attack took place were admitted to show "a lustful disposition and the trend of mind and inclination of the defendane").

29. See 2 Wignore, Evidence $\$ 398$ (3d ed. 1940). Cf. Grigsby v. Commonwcalth, 299 Ky. 721, 187 S.W.2d 259 (1945); Graham v. State, 125 Tex. Crim. 210, 67 S.W.2d 296 (1933).

30. I Wignore, Evidence $\$ 62$ n.l (3d ed. 1946).

31. A classic argument in favor of admitting such evidence appears in People v. Abbot, 19 Wend. 192, 195 (N.Y. 183S) : "[Will] you not more readily infer assent i" the practised Messalina, in loose attire, than in the reserved and virtuous Lucretia" $\mathrm{Sco}$ also People v. Cox, 383 Ill. 617, 622, 50 N.E.2d 758, 760 (1943). 
though generally considered relevant, ${ }^{32}$ some jurisdictions bar this evidence on the grounds that prejudice and confusion of the issues would result from its introduction. ${ }^{33}$

Since acts alleged to constitute rape occur so frequently in private, the facts known only by the complaining witness and the defenclant, the credibility of the parties must have an important bearing on the fact finder's decision. Rules of evidence permit the admission of material for purposes of impeachment, which theoretically does not bear directly on the issue of consent. The general reputation in the community for veracity of every witness is admissible for this purpose. ${ }^{34}$ And if the defendant takes the stand in his own behalf, evidence of prior convictions of any crime are admitted on the old theory of "once a felon always a liar."35 Many jurisdictions permit attack on the woman's credibility by evidence of her failure to complain promptly. ${ }^{\text {s0 }}$ The theory supporting this rule is that a woman who submits involuntarily to sexual intercourse is likely to speak out against her attacker at the earliest opportunity. ${ }^{37}$

Traditionally, American courts have allowed heavy reliance by juries on "demeanor evidence" to gauge credibility. ${ }^{38}$ This emphasis reveals a faith in the lay juror's ability to judge a witness' truthfulness from his or her appearance on the stand, dress, promptness in answering questions, tone of

32. State v. Wood, 59 Ariz. 48, 122 P.2d 416 (1942); People v. Battilana, 52 Cal. App.2d 685, 126 P.2d 923 (1942); Grigsby v. Commonwealth, $299 \mathrm{Ky} .721,187$ S.W.2d 259 (1945).

33. Stone v. State, 243 Ala. 605, 11 So.2d 386 (1943); State v. Howard, 5 W.W. Harr. 143, 159 Atl. 841 (Del. O. \& T. 1932); State v. Severns, 13 Wash.2d 542, 125 P.2d 659 (1942). Wigmore would admit such evidence on the theory that of the possible injustices, he prefers the innocent woman robbed of her revenge to the innocent man falsely convicted. 1 WigMore, EVIDENCE $\$ 200$ (3d ed. 1940).

34. The verbal distinction here is that impeachment evidence goes to the likelihood of a witness' truthfulness, rather than directly to the likelihood of the occurrence of rape. See 3 WigMore, EvIDENCE $\$ 922-5$ (3d ed. 1950).

35. 3 WigMORE, EVIDENCE $\$ 926$ (3d ed. 1940).

36. 4 WignoRE, Evidence 1135 (3d ed. 1940); 3 id. at 1042. The precise function of the rule is not clear. Usually held to go to the credibility of the complaining witness, State v. Palmer, 344 Mo. 1063, 130 S.W.2d 599 (1939); see Stitely v. Únited States, 61 A.2d 491, 492 (D.C. Mun. Ct. App. 1948), her failure to complain promptly has sometimes been limited to veracity concerning only the issue of consent. Cf. Clark v. State, 28 Ala. App. 448, 186 So. 778 (1939); State v. Black, 204 So. Car. 414, 29 S.E.2d 675 (1944). Some courts have gone a step further and admitted it on the merits of consent. See, e.g., State v. Risen, 192 Ore. 557, 563, 235 P.2d 764, 766 (1951). This conflict is particularly evident in statutory rape cases where consent is irrelevant. Compare Pcople v. Freemont, 47 Cal. App.2d 341, 117 P.2d 891 (1941); State v. Strable, 228 Iowa 886, 293 N.W. 441 (1940), with State v. Haston, 64 Ariz. 72, 166 P.2d 141 (1946). Sce also People v. Gump, 17 Cal. App.2d 221, 223, 61 P.2d 970, 971 (1936).

37. See, e.g., Adams v. Commonwealth, $219 \mathrm{Ky} .711,714,294$ S.W. 151, 152 (1927).

38. 3 WigAore, EVIDENCE $\S 946$ (3d ed. 1940). 
voice, and general attitude. ${ }^{39}$ However, the difficulties in determining the truth in rape allegations, coupled with the unusual inducement to malicious or psychopathic accusation inherent in the sexual nature of the crime, ${ }^{20}$ have led many writers to urge the freer introduction of the findings of psychiatric examinations. 11 Recently, such expert testimony has found greater favor in the eyes of the law, and, despite the opinion rule, ${ }^{22}$ this evidence has been widely admitted. ${ }^{43}$

Less than half the states provide a further check on the veracity of the complaining witness by requiring independent corroboration of her story to sustain a guilty verdict. ${ }^{44}$ There is great variation among these states, and rarely a clearly defined rule within a state, about the surt of evidence vhich

39. See, e.g., Blair v. State, 69 Ark. 558, 64 S.W. 948 (1901); Mlorris v. State, $5 S$ Ga. App. 383, 198 S.E. 554 (1938); Hauser v. People, 210 Ill. 253, 71 N.E. 416 (1904).

40. See 4 Freud, Collected Papers 227 (Reviere's transl. 1925): There are some "women who after the ... intercourse ... openly express their enmity against the man by reviling him, threatening to strike him or even actually striling him" See also 3 Wigniore, EUIDENCE \$924(a) (3d ed. 1940).

41. See 3 Wigarore, Evinence $\$ 924$ (a) (3d ed. 1940) (includes the vievs of Drs. Menninger, W. A. White, W. F. Lorenz).

42. See 7 Wigaiore, Entence $\$ 1983$ (3d ed. 1940).

43. Cf. Coffin v. Reichard, 148 F.2d 278 (6th Cir. 1945); United States v. Hiss, $8 \$$ F. Supp. 559 (S.D.N.Y. 1950). See also Machtinger. Psychialric Testinony for the Inpeachntent of Witnesses in Sex Cases, 39 I. CRnr. Law \& Canmoscay 750 (1949); Comment, 59 Yale L.J. 1324, 1338 (1950); Note, 26 Ikv. L.J. 98 (1950).

44. 7 Wigarore, EvideNCE $\$ 2061$ (3d ed. 1940). Five Amerian jurisdictions have specific statutory requirements of corroboration. Gs. Cors Ass. $\$ 20-1304$ (1936); IowA Code And. $\$ 782.4$ (1950) ; Mirss. Cone Ans. $\$ 2360$ (1942); N.Y. Perial Law \$2013 (MIckinney 1944) ; TENn. Cone ANn. \$107\&6 (Williams 1934). See State v. Ervin, 227 Iowa 181, 287 N.W. 843 (1939); Stapleman v. State, 150 Neb. 4i0, 34 N.W.2d 907 (1948) ; People v. Romano, 253 App. Div. 724, 300 N.Y. Supp. 365 (1937), off'd, 277 N.Y. 619, 14 N.E.2d 191 (1938), But cf. State v. Lahmon, 231 Iowa 44S, 1 N.W.2d 629 (1942). Other states require corroboration only if the complaining witness" story "is physically impossible, or so incredible that no reasonable man could belicve it." State v. Haston, 64 Ariz. 72, 166 P.2d 141 (1946) ; MeDaniel v. Commonwealth, 30S Ky. 132, 213 S.W.2d 1007 (1948) ; Young v. Commonwenlth, 185 Va. 1032, 40 S.E.2d 805 (1947); or if her story is improbable or contradictory, State v. Smith, 237 S.W. 482, 4S5 (MO. 1922) ; Day v. State, 29 Okla. Crim. Rep. 49, 232 Pac. 122 (1925); or if the story of the prosecutrix is not "clear and convincing," People v. Burns, 364 Ill. 49, 4 N.E.2d 26, 29 (1936) ; State v. Ball, 133 S.W.2d 414 (110. 1939); or if the charge has been denied by the defendant, People v. Grudecki, 373 Ill. 536, 27 N.E.2d 51 (1940); or if discredited by other evidence, State v. Siebke, 216 Minn. 1S1, 12 N.W.2d 186 (1943); or if the complaining witness has failed to make prompt complaint of the offence, Ex farte Merrill, 150 Tex. Crim. Rep. 365, 201 S.W.2d 232 (1947); or if the girl's character has been impeached, State v. Elsen, 68 Idaho 50, 187 P.2d 976 (1947). Several jurisdictions do not require corroboration of the complaining vitness in any case. People v. Gidney, 10 Cal.2A 138, 73 P.2d 1186 (1937) ; People v. Gump, 17 Cal. App.2d 221, 61 P.2d 970 (1936); Commonwealth v. Ebert, 146 Pa. Super 362, 22 A.2d 610 (1941); State v. Gatlin, 203 
constitutes corroboration, ${ }^{45}$ when it must be offered, ${ }^{46}$ or the extent to which it must support the allegations. ${ }^{47}$ Generally, a state which requires corroboration will demand, either in all cases or only when the woman's story sounds improbable, ${ }^{48}$ some evidence (even of slight probative force) ${ }^{40}$ from a source other than the woman herself, which supports her claim.

In some rape cases a presumption of non-consent ${ }^{50}$ supplies the legal requirement of a woman's attitude of opposition. When a man has sexual

S.C. 414,38 S.E.2d 238 (1946); Taylor v. Commonwealth, 180 Va. 413, 23 S.E.2d 139) (1942). Corroboration has been held unnecessary even when her reputation for veracity and chastity was bad. Herndon v. State, 2 Ala. App. 118, 56 So. 85 (1911). In some jurisdictions the status of the requirement is unclear. Compare People v. Polak, 360 Ill. 440, 196 N.E. 513 (1935), with People v. Nelson, 360 Ill. 562, 196 N.E. 726 (1935). See also McQueary v. People, 48 Colo. 214, 219-20, 110 Pac. 210, 213 (1910).

45. Kell v. State, 188 Ga. 670,4 S.E.2d 596 (1939) (signs of a physical struggle); State v. Marshall, 354 Mo. 312, 189 S.W.2d 301 (1945) (appearance and physical condition of woman after alleged attack); Prokop v. State, 148 Neb. 582, 28 N.W.2d 200 (1947) (same). See also People v. Mummert, 57 Cal. App.2d 849, 135 P.2d 665 (1943) (findings of chemical analysis); State v. Sims, 241 Iowa 641, 40 N.W.2d 463 (1950) (defendant's confession or admission). However, evidence of defendant's opportunity to commit the act will not be accepted as corroboration, State v. Jones, 62 Idaho 552, 113 P.2d 1106 (1941) ; State v. Whitney, 220 Iowa 1203, 263 N.W. 803 (1935). For corroboration in statutory rape cases, see note 71 infra.

46. See note 44 supra.

47. The most inclusive rule is that corroboration must extend to every material fact upon which the charge is based-that is, a crime was committed and by the defendant. People v. Croes, 285 N.Y. 279, 34 N.E.2d 320 (1941). Or it may be necessary to corroborate the complaining witness on "material facts and circumstances supporting her testimony," Wiedeman v. State, 141 Neb. 579, 4 N.W.2d 566 (1942). A more elusive rule is that complainant's testimony must be given "such dignity as to give it weight with the jury," DeWitt v. State, 79 Okla. Crim. 136, 152 P.2d 284 (1944). There may be a rcquirement for corroboration of some material fact that connects the defendant with the crime. State v. Lahmon, 231 Iowa 448, 1 N.W.2d 629 (1942). Or the sufficiency of corroboration may be a jury question. Dorsey v. State, 204 Ga. 345, 49 S.E.2d 886 (1948).

48. See note 44 supra.

49. State v. Siebke, 216 Minn. 181, 12 N.W.2d 186 (1943); Stapleman v. State, 150 Neb. 460,34 N.W.2d 907 (1948); Hulsey v. State, 65 Okla. Crim. 382, 87 P.2d 1110 (1939); Taylor v. Commonwealth, 180 Va. 413, 23 S.E.2d 139 (1942).

50. The "presumption of non-consent" as used in this Comment does not refer to a presumption in the usual legal sense. Instead, the phrase refers to the presumption necessarily accompanying the conclusion of rape in those situations where a woman's actual consent was legally inoperative or her physical condition prevented her from expressing any attitude toward the act. To find that these acts constitute rape, the law must assume that, had she been aware of the facts and capable of understanding their significance, the woman would have denied consent.

The presumption here, and in the statutory rape cases, may be explained by the theory that the victim must have a "definite minimum of intelligent understanding" of the "true facts" of the situation before her consent may be considered operative. Puttkammer, Consent In Rape, 19 ILL. L. REv. 410 (1925). 
intercourse with a sleeping or stuporous woman, toward the act because she is unaware that it is about to occur. The law seems to assume that had the woman been apprised of the facts, she would have opposed coitus. So the law, speaking for the woman, denies her consent. Moreover, since the act itself deprives the woman of her right to withhold consent, the man is guilty, even if not responsible fur inducing the wamas: stuporous condition. ${ }^{52}$

Often overlapping this category, and involving a similar presumption, are the few cases of rape by fraud. ${ }^{53}$ Typically, the woman agrees to the act because of the man's false representations-that sexual intercourse was a necessary medical treatment ${ }^{54}$ or that he was her husband. ${ }^{55}$ Some courts reason that the woman's awareness of the "nature" of the act was so impeded by the defendant's misrepresentations that she was incapable of giving operative consent. 56 The rarity of these cases today may be partly explained by the difficulty of presenting a convincing picture of such grossly impeded comprehension to skeptical jurors; the scene depicted may resemble more an artful seduction than forcible intercourse.5i Thus, other courts have held the woman's actual consent to the physical penetration of her organs, of which she was admittedly aware, a valid defense to the forcible rape charge. $\bar{s}$

51. See, e.g., Kan. Gen. Stat. Ann. $\$ 21-425$ (1949); X.Y. Peiral Cone $\$ 2010(4)$ (McKinney 1944); State v. Stroud, 240 S.W.2d 111 (Mo. 1951); State v. Weleh, 191 31o. 179, 89 S.W. 945 (1905).

There are virtually no reported cases of stupor induced by drugs, but the rule seems to be that coitus constitutes rape only if the potion rendered the woman ineapable of making a conscious choice. E.g., Evans v. State, 67 Ga. App. (31, 21 S.E.2d 336 (1942). Thus, where the drug is an aphrodisiac, which excites unusual sexual desires, penetration cannot be termed rape because the woman retained her puwers. The drug is considered a device of the seducer. See State v. Lung, 21 Nev. 209, 23 Pac. 235 (1891).

52. N.Y. Penal LAws $\$ 2010$ (4) (Aickinney 1944); Commonwealth v. Burke, 105 Mlass. 376 (1870). Contra: Calir. Penal Cone $\$ 261(4)$ (Deering 1949).

53. See Cal. Penal Code $\$ 261$ (6) (Deering 1949): N.D. Kex. Cone $\$ 12-3001(7)$ (1943) ; 21 OrLA. Stat. ANn. \$1111(8) (1937); Texw. Cote Awn. \$1072 (Williams 1934): 2 Tex. Penal Code ANw. art. 1183 (Vernon 1925); Eberhart v. State, 134 Ind. 651,34 X.E. 637 (1593). Since fraud usually requires the active deceptiun of the girl by some trick or "stratagem" of the defendant, c.g.. 2 TEx. Pexal CuDE art. 1186 (Vernon 1925), most of these charges are tried as rape upon an unconscious voman. Lewis $v$. State. 30 Ala. 54 (1857) ; Huffman v. State, 46 Tex. Crim. Rep. 428 , 80 S.W. 625 (1904); Payne v. State, 38 Tex. Crim. Rep. 494, 43 S.W. 515 (1897). See alsy PLustwwe, SEx AND THE LAW 167-S (1951).

54. Pomeroy v. State, 94 Ind. 96 (18\$3) : Walter v. People, 50 Barb. 144 (N.Y. Sup. Ct. 1867). Contra: Moran v. People, 25 Mich. 356 (1872).

55. See Draughn v. State, 12 Olla. Crim. 479, 158 Pac. 800 (1916); Willserson v. State, 60 Tex. Crim. Rep. 3sS, 131 S.W. 1108 (1910). But cf. Lee v. State, 44 Tex: Crim. Rep. 354, 72 S.W. 1005 (1902).

56. See cases cited in notes 54 and $\mathbf{5 5}$ supra.

57. See, e.g., People v. Royal, 53 Cal. 62 (1878).

58. Moran v. People, 25 Mich. 356 (1872); Lee v. State, 44 Tes Crim. Rep. 354, 72 S.W. 1005 (1902). 


\section{Statutory Rape}

The presumption of non-consent is most frequently applied in "statutory" rape cases and has the effect of negating the girl's actual consent. In nearly all jurisdictions, "carnal knowledge or abuse" of a girl below a fixed age (varying from 14 to 21 years) ${ }^{60}$ or mentally incapable of "understanding the nature of the act" because of insanity ${ }^{61}$ or imbecility ${ }^{62}$ constitutes rape; her actual consent is legally inoperative. ${ }^{63}$ Some states provide different punishments according to the age group to which the girl belongs: the younger the girl, the heavier the penalty. ${ }^{64}$ Other states absolve the male if he is below a certain age or younger than the girl. ${ }^{\text {c5 }}$ Because the girl's actual age determines her capacity to give operative consent, the defendant's belief, however reasonable, as to her age is irrelevant.60 Yet when the girl is alleged to be imbecilic or insane, some courts will acquit the defendant if he can prove his reasonable belief that she was mentally competent. ${ }^{67}$ Since in all statutory rape cases, however, the girl's attitude toward the act is not an element of the crime, no proof need be offered of her non-consent. ${ }^{08}$

A minority of states regard sexual intercourse with an underage girl as

59. Although all rape is "statutory" in the sense that the crime is always included in criminal statutes, the term "statutory" has been commonly reserved for intercourse with a minor or mentally disabled girl. This crime was unknown to the early common law. 4 BL. Coms. 210 (Lewis ed. 1902).

60. E.g., GA. CODE ANn. $§ 26-1303$ (1936) (age 14) ; MAss. ANs. LAws, c. 265, §23 (1933) (age 16) ; Tens. Code ANn. $\$ 10,786$ (Williams 1934) (age 21). For an exhattstive study of statutory rape law in the United States, see Holnar, Staturony Rapr: (unpublished ms. in Yale Law Library, 1952).

61. E.g., Ind.-Stat. ANn., c. 42, \$10-4201 (Burns 1933); N.Y. Penal LaW \&2010 (1) (McKinney 1944), People v. Palvino, 216 App. Div. 319, 214 N.Y. Supp. 577 (1926).

62. E.g., N.Y. Penal Code \$2010(1) (McKinney 1944); VA. Code ANN. \$18-54 (Michie 1950) (which includes, uniquely, inmates of institutions for the deaf, dumb, or blind).

63. Owens v. State, 29 Ala. App. 53, 191 So. 899, cert. denied, 238 Ala، 519, 191 So. 903 (1939); Taylor v. State, 55 Ariz. 29, 97 P.2d 927 (1940); State v. Lawson, 136 S.W.2d 992 (Mo. 1940). See Ploscowe, Sex and the Law 175-6 (1951).

64. E.g., Minn. Stat. Ann. § 617.02(1),(2),(3) (1947) (10 or under-life imprisonment; $10-14-7$ to 30 year sentence; $14-18-7$ years in state prison or 1 year in county jail).

65. E.g., Mrss. Code ANs. $\$ 2359$ (1942) (male must be older than girl if she is in 12-18 age group; lack of chastity also a defense); N.J. STAT. ANs. $\$ 2: 163-1$ (1939) (male must be over 16).

66. E.g., Manship v. People, 99 Colo. 1, 58 P.2d 1215 (1936); State v. Wade, 224 N.C. 760,32 S.E.2d 314 (1944).

67. State v. Robinson, 345 Mo. 897, 136 S.W.2d 1008 (1940); Commonwealth v. Stephens, 143 Pa. Super. 394, 17 A.2d 919 (1941). But cf. Stephenson v. State, 35 Ala. App. 379, 48 So.2d 255, cert. denied, 254 Ala. 313, 48 So.2d 259 (1950).

68. See cases cited in note 63 supra. 
rape only if she was previously chaste ${ }^{63}$ or had a good reputation. 70 When chastity is an element of the crime, evidence of specific prior acts of intercourse is admissible to bar a guilty verdict. ${ }^{71}$ Under the reputation test, however, specific acts are inadmissible. ${ }^{i 2}$

\section{The Consent Standard in Forcible Rape}

\section{Difficulties with the Standardia}

In common usage the word "consent" refers to a self-perceived attitude;" one consents when he himself thinks he consents. it And if a woman were to use the word "consent" to describe her attitude (as she perceives it) toward an act of coitus, both she and others would conclude that she had, in fact, consented. However, in a courtroom demonstration of the attitude, the fact finder must often rely heavily on the woman's behavior at the time of the alleged crime. And the consequences to the male may depend largely on the accuracy of the woman's post-facto report to others of her attitude. Therefore, for the consent standard to function without jeopardizing innocent males, the woman must have a clearly formulated, self-perceived attitude toward the act, reliably evidenced by her behavior at the scene, and accurately recalled.

69. E.g., FlA. Stat. ANn. $\$ 794.05$ (1944); N.C. Ger. Stat. $\$ 14-26$ (1943); 21 ORLa. Stat. ANn. $\$ 1111$ (1937); W.VA. CODE ANN. $\$ 5930$ (1949).

70. 1S PA. Stat. Avn. $\$ 4721$ (Purdon 1945) (the girl must also consent); Tenis. CODE ANN. $\$ 107 \$ 6$ (Williams 1934) (evidence of a bad reputation admissible if girl is over 14; lack of chastity a defense if she is over 12).

71. E.g., Ledbetter v. State, 184 Tenn. 396, 199 S.W.2d 112 (1947). However, even in jurisdictions where chastity is not an element of the crime, cuurts may admit evidence of prior acts between the parties to corroborate the girl's claim that the act in question occurred. E.g., People v. Smittcamp, 70 Cal. App.2d 741, 161 P.2d 983 (1945); Parlsey v. State, 59 Okla. Crim. 45, 56 P.2d 14 (1936). Only Pennsylvania, with a reputation test, holds such evidence inadmissible. See note 72 infro.

72. Commonwealth v. San Juan, $129 \mathrm{~Pa}$. Super. 179, 195 Atl. 433 (1938).

73. The Editors are indebted to MIr. Alan A. Stone of the Yale School of Mredicine for his valuable contribution to the development of this and later sections.

74. "[A]n attitude can be defined as an enduring organizalion of molicutiossal, entotional, perceptual, and cognitize processes with respect to some aspect of the individual's world." Krech \& CRutchfield, Theory and Probless on Soeril Psychology 152 (1st ed. 1948).

75. Consistency with this definition of consent seems to demand that a man be punished if he has intercourse with a woman who would label her attitude non-consensual, regardless of the nature of the coercion which induced her submission. But the law makes an evaluative distinction between the coercive elements of (1) threat of bodily injury and (2) other forms of threat. Although the latter may in fact have been more urgent in terms of the personality needs of the particular woman involved, the law refuses to treat them as anything more than reasons for giving consent, consent which bars conviction. See text at note 1S supra. This value doctrine reflects the law's (useful operationally, but ethically questionable) belief that no fear justifies a woman's surrender of her body "against her will," except the fear of physical harm. 
In situations resembling the stereotyped sexual attack ${ }^{70}$-a sudden sexual demand on a dark and isolated street by one or more unknown men, perhaps intoxicated and armed-the woman is likely to have a prepared reaction clearly structured in opposition to the act. ${ }^{77}$ The circumstances alone appear to justify the assumption that the woman's submission was non-consensual. In such cases, therefore, the fact finder is not compelled to rely heavily on the woman's behavior, and there is relatively little danger that the consent standard will lead to an unjust decision.

But where the circumstances of the encounter differ from the stereotyped attack-as when the parties were previously acquainted, perhaps to the extent of a "dating" relationship, and the encounter occurred in an apartment to which they both went willingly - one cannot so easily assume the woman's attitude of opposition. ${ }^{78}$ Here, the behavior of both parties must be more heavily relied on to evince the woman's attitude toward the act. The woman's behavior ordinarily may be an accurate guide to her attitude. But sometimes the behavior, controlled by personality forces other than those which determine the consciously perceived attitude, will contradict the woman's selfperceived disposition toward the act. ${ }^{70}$ When her behavior looks like resistance although her attitude is one of consent, injustice may be done the man by the woman's subsequent accusation. Many women, for example, require as a part of preliminary "love play" aggressive overtures by the man. Often their erotic pleasure may be enhanced by, or even depend upon, an accompanying physical struggle. ${ }^{80}$ The "love bite" is a common, if mild, sign of the aggressive component in the sex act. ${ }^{81}$ And the tangible signs of struggle may survive to support a subsequent accusation by the woman.

In some cases, the woman's conscious response to the sexual demands of a man may not accurately be labeled either "consent" or "non-consent" in the sense of a definite positive or negative reaction. ${ }^{82}$ Consent, like any other conscious attitude, results from a particular organization of needs in an individual at any given moment $;{ }^{83}$ but-especially where sexual stimuli are

76. See, e.g., Farreis, Studs Lonigan pt. 2, 408-10 (Mod. Lib. ed. 1938).

77. See Sherif, Group Influences Upon the Formation Of Norms and Attindes, in Newcomb \& Hartley, Readings In Soctal Psychology 77, 85 (1947). See also Ploscowe, SeX ANd the Law 169 (1951).

78. See, e.g., State v. Hoffman, 228 Wis. 235, 280 N.W. 357 (1938).

79. See Feniched, The Psychoanalytic Theory of Neurosis 237 (1945).

80. See Freud, New Introductory Lectures on Psychoanalysis 158 (Sprout'g transl. 1933); SaUl, ENotional Maturity 139 (1947).

81. "Among some members of our own society intense sexual arousal may lead a man or woman to pinch, scratch, bite or otherwise bring pain to the partner. And for at least some individuals a mildly painful stimulus can, under certain conditions, result in increased sexual excitement." Ford \& BeAch, Patterns of Sexunl Benavior 55 (1952).

82. See Allport, G. W., Personality, A Psychological Interpretation 184 (1937) ; Murphy, Personality 298 et seq. (1947).

83. See note 74 sipra. See also Murray, Explorations in Personality 67-76, 88 (1938). 
involved-a person may have no clear attitude. $\$$ The complex set of personality needs, many of them rooted in the unconscious ${ }^{85}$ and often competing with each other, may produce an ambivalent and unclear mixture of desire and fear even in the "normal" person..$^{80}$ For instance, a woman's need for sexual satisfaction may lead to the unconscious desire for forceful penetration, ${ }^{s-}$ the coercion serving neatly to avoid the guilt feelings which might arise after willing participation. $\$ s$ But the desire thus generated for the "attack" is likely to clash with the civilized "superego" 69 which vehemently rejects such unrestrained sexuality. ${ }^{30}$ At the moment of genital entry, neither force may have gained dominance and no positive or negative attitude formulated.

Where such an attitude of ambivalence exists, the woman may, nonetheless, exhibit behavior which would lead the fact finder to conclude that she opposed the act. To illustrate: a woman whose sexual desire and superego are in conflict may alternate rapidly between "approach" and "rejection" responses to the man, first scratching and pushing him, at the next moment suliciting his caress. ${ }^{91}$ In other women, the anxiety resulting from this conflict of needs

S4. See $i d$. at $8 S$.

85. For a delineation between the mental spheres of "conscious" and "unconscious," see FREUd, The Ego and the Id 9-1S (Riviere's transl. 1927).

86. See note S4 supra.

87. "If children at so tender an age witness the sexual act between adults, for which an occasion is furnished by the conviction of the adults that little children cannot understand anything sexual, they cannot help conceiving the sexual act as a lind of maltreating or overpowering; that is, it impresses them in a sadistic sense." Freud, Bustc Wurumcs 596 (Brill's transl. 1938). See also Fenicher, op. cit. supra note 74, at 214.

88. See Alexander, Fundanentals of Psychoanalysis 122 (1948).

89. In the attempt to classify and describe the complex forces in the personality which direct the actions and attitudes of people, many writers have followed Freud's conception of the "anatomy of the mental personality." Id. at $\$ 2$. Freud deccribes the "superego" as the organization of learned social dispositions which impose negative restraints on the more primitive drives, and particularly upon the expression of sexual energy (libido). Ibid.

90. "It [the superego] sets up an ideal standard, according to which sesuality is prohibited and aggression pronounced to be antisocial." ANwA FREUd, The ECo NiD TBE Jiechanisus of Defense 59 (1937). See also description of repression as a defense mechanism of the ego in ALEXANDER, op. cit. supra note 88 , at 96.

91. "Needs are commonly related to their opposites in a temporal configuration. A phase of Dominance is succeeded by a phase of Deference. A wave of Aggression is followed by a wave of Nurturance or of Abasement" MIURRAy, Explozitions In PESONALITY $S S$ (1938). Often the dynamic justification for the alternation of dominant necds is the need to "undo" the effects of the previous need or behavior. FerriczEL, op. cit. stipro note 79 , at 153 . Thus a person who displays inviting sexual behavior, obedient to the need for sexual gratification or affection, may find that the resulting sex flay stirs un serious guilt feelings and half-perceived anxiety. The opposite mode of behavior, that of outright physical rejection, must then "undo" the guilt or anxiety. This behavior, in turn, frustrates needs of affection and nurturance, and in its turn must be "undone" It is suggested that in situations of intimacy, this conflict, if it exists in a woman, may be brought to sharp and rapid behavioral demonstration. 
may cause her to flee from the situation of discomfort, either physically by running away, or symbolically by retreating to such infantile behavior as crying. ${ }^{.2}$ The scratches, flight, and crying constitute admissible and compelling evidence of non-consent. ${ }^{03}$ But the conclusion of rape in this situation may be inconsistent with the meaning of the consent standard and unjust to the man. There is no explicit provision in the law for the woman's attitude of ambivalence. But the universal rule that the state has the burden of proving the woman's non-consent ${ }^{94}$ indicates that if she lacks a definite negative attitude, the law will consider the woman to have consented. And fairness to the male suggests a conclusion of not guilty, despite signs of aggression, if his act was not contrary to the woman's formulated wishes.

The woman's unreliable behavior presents less serious dangers for the man if she later accurately recalls her attitude at the time of the sexual adventure. But since the memory process commonly alters the content of a perception, the woman's recall will often be tailored to fit personality needs which become dominant after the act. ${ }^{95}$ The stronger these needs and the more ambivalent the original attitude, the greater is the subsequent distortion. ${ }^{90}$ Most women probably have a strong need to adopt the socially acceptable motive and thus some may honestly believe that they were forced to submit over their mental opposition. ${ }^{97}$ Particularly since most reports and complaints are made to parents, police, or prosecutors, the woman is likely to recall her attitude as one of opposition.88 Reporting to such "authority figures" encourages the dominance of superego needs in the woman. ${ }^{09}$ The distorted recall by-passes

92. "Acquired mechanisms are apt to break down under emotional stress, fatigue, the sudden impact of external stimuli, or rapid change in external conditions. Regression to earlier behavior patterns can be observed, and with it the disintegration of set behavior patterns, which resolve into their constituent parts." AlExander, op. cit. supra note 88, at 129.

93. See note 26 sitpra.

94. E.g., State v. Wargo, 83 N.H. 532, 145 Atl. 456 (1929) ; Parrett v. Statc, 200 Ind. 7, 159 N.E. 755 (1928) ; State v. Egner, 317 Mo. 457, 296 S.W. 145 (1927) ; Nichols v. State, 138 Tex. Crim. Rep. 144, 134 S.W.2d 260 (1939). There is no requirement that the defendant demonstrate to the court that the woman actually offered her consent to the act. E.g., Stringer v. State, 102 Tex. Crim. 333, 278 S.W. 208 (1925). See also Puttkammer, Consent in Rape, 19 ILL. L. REv. 410 (1925).

95. See KRECH \& CRUTCHField, op. cit. supra note 74, at 133 .

96. See Bartlett, Social Factors in Recall in Newcomb \& Hartley, Readings in Social Psychology 75 (1947).

97. See Krech \& CRUTCHField, op. cit. supra note 74, at 164. See note 77 supra.

98. See note 96 supra.

99. The term "authority figure" refers to a person who represents the demands of society to conform and repress instinctual modes of behavior which are antithetical to community living. In the early formative years of a person's life, he customarily develops a strong emotional tie with a parent or a parent-substitute. Through this "identification," the "superego" or conscience is formulated. The child, at the same time, learns to inhibit his infantile, instinctive behavior patterns and to develop "adult" means of coping with 
the explicit legal pronouncement that a post-facto attitude toward the act has no legal significance. ${ }^{100}$

False reports may also stem from other sources. A rape accusation is so potent a weapon against a man that a woman may deliberately and maliciously distort her report of the sexual encounter to secure for herself money, marriage, or revenge. ${ }^{101}$ Deliberate falsification, however, lends itself to detection by law enforcement techniques. More serious is the problem of the psychopathic woman. She may completely fabricate a forceful sexual act yet be unaware of the fanciful origin of her complaint. ${ }^{102} \mathrm{Her}$ belief, just as the distorted recall of the "normal" girl, may lead to accusation and possible conviction since, contrary to popular opinion, the accounts of these girls are often highly convincing ${ }^{103}$ and immune to the lie detector. ${ }^{104}$ Only highly trained medical men can detect the psychopathic origin of the accusation.

the world. Saul, Exomonal Maturity 92 (1947). The authority figure may be someone in later life who stands in the role of the original parent-teacher. As a representative of the person who has encouraged socially conforming behavior, which usually includes the repression of sexuality, the police officer or public prosecutor may elicit from a girl the responses which she would offer to the parent. See KRECH \& CRUTCrifiend, of cit. supro note 74, at 33 et seq. (1948). Furthermore, in the case of a complaint of rape, the untrained interviewer is likely to make, albeit unintentionally, the errors most likely to

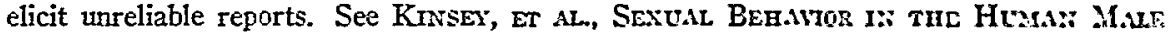
35-62 (1949).

100. E.g., Commonwealth v. Slattery, 147 MIass. 423, is N.E. 399 (1S\$S). See Minler, CrRunal Law \$ 58 (1934).

101. "She [the complaining witness] further testified ... that what she swore on the former trial was false; that she had already become a girl of bad character at the time the accused had relations with her, and that she was induced to make false statements by her mother to enable the latter to force money from the [accused] and also to breal: up the criminal relations existing between him and her sister Mraggie; that is to separate them, so that her mother could obtain money by using Mlaggie as a lure for other men." Dunn v. State, 127 Tenn. 267, 281, 154 S.W. 969, 972 (1913); see also State v. Snow, 252 S.W. 629, (Mo. Sup. Ct. 1923); Allen v. State, 10 OHla. Crim. App. 55, 134 Pac. 91 (1913) ; Martinez v. State, 123 Tex Crim. App. 572, 59 S.W.2d 410 (1933). West, $A$ Psychological Theory of Law in Interpretations of Mlowera Leúll Pnilusophies 767, 780 (Sayre ed. 1947) ; Transcript of Interview with Mr. Edward Silver, Ass't District Attorney, Kings County, New York, March, 1952, pp. 4-5, on file at the Yale Law Library (hereinafter referred to as INTERvIEw).

102. The feminine wish to be subjected to a sexual attack may become the subject of an hallucination. See 4 Freud, Collected P.APERs 145 (Riviere's transl. 194S).

103. See statement of Drs. William Healy, Karl A. Menninger, William A. White, W. F. Lorenz, reprinted in 3 Wigarone $\$ 924$ (a). See also 1 Devrsen, Psycnougar of WOMIEN 255-6 (1944).

104. "The Lie Detector, as is well known, is based on the principle that an emotional disturbance will register in the physiological reactions. It is assumed that, if an individual should lie about some matter, he will develop a certain amount of ansiety due to pangs of conscience, and this anxiety in turn will cause his blood pressure to rise, his respiratory and pulse rates to increase.

"It would seem, however, that theoretically there are sume significant deviations in 
With the crime of rape based upon the participating woman's stbjective attitude, which may be unclear even to herself, inaccurately reflected in her behavior, and easily distorted in recall, consent seems, in some cases, to be a nebulous standard of criminality. Thus the question arises: why must we judge the legal consequences of an act of coitus by the woman's subjective attitude? The answer lies in the role of sex in our social organization.

\section{Consent in the Social Structure}

All societies seek to control and direct sexual energy in order to maintain their group structure and function. ${ }^{105}$ Unchanneled, the sex drive threatens to disrupt patterns of social and family organization. ${ }^{108}$ Properly controlled, on the other hand, sexual energy moves people into relationships and activities which sustain the group. The channeling of sexuality into marriage is crucial to all societies and espoused as a desirable goal by virtually all component sub-groups. ${ }^{107}$ In our society, sexual taboos, often enacted into law, buttress a system of monogamy based upon the "free bargaining" of the potential spouses. Within this process, the woman's power to withhold or grant sexual access is an important bargaining weapon. ${ }^{108}$ Beyond the use of sexuality in marriage, it is difficult to generalize on the socially approved allocation of

reactions to the test which should make the findings of the lie detector somewhat dubious. For example, there is the asocial, childish personality type, the individual who has no appreciation of the significance of falsification. . . . This individual can very well utter any number of lies without pangs of conscience or anxieties. . . Finally we come to the pathological liar type which, owing to a serious emotional derangement, lost the ability to differentiate between reality and fiction. The pathological liar certainly will not show any significant reaction to the lie detector test." Floch, Limitalions of the Lie Defcctor, 40 J. Crim. L. \& Criminology 651-2 (1950).

105. "Society . . . cannot remain indifferent to sex but must seek to bring it under control. Possibly in man's long history there have been peoples who have failed to subject the sexual impulse to regulation. If so, none has survived, for the social control of sex is today a cultural universal." Murdock, Soctal Structure 260 (1949). See also Murdock, $A$ Comparative Anthropological Approach, 36 J. Soc. HYGIENE 133, 134 (1950).

106. "The imperious drive of sex is capable of impelling individuals, reckless of consequences while under its spell, toward behavior which may imperial or disrupt the cooperative relationships upon which social life depends. The countless interpersonal bonds out of which human association is forged, complex and often delicately balanced, can ill suffer the strain of the frustrations and aggressions inevitably generated by indiscriminate competition over sexual favors." Murdock, Social. Structure 260 (1949).

107. See Wilson \& Kolb, Soctological Afalysis 588 (1949).

108. See note 113 infra. And see KInSEY, ET Al., op. cit. sippra note 99, at 595 . It is interesting to note that we do not recognize this function of sex in the man. He is not considered to have the same "economic" right in his sexual capacities, and the law does not protect him from the invasion of the "right" by a woman. The role of the man as the initiator of sexual relations and the active partner in the act, which is, perhaps, contrary to fact in many instances, also contributes to the assumption that a man cannot be "raped" by a woman. See note 2 supra. 
sexual energy. ${ }^{100}$ However, many sub-groups and individual members of society, more or less overtly, recognize the appropriateness of non-marital relationships fostered by the woman's decision to participate in se:sual union.11n In all cases the law of rape protects the woman's discretion by proscribing coitus contrary to her wishes.

The assumption apparently underlying the protection offered to the woman's sexual decisions is that they will be in harmony with cultural objectives.111 The assumption is largely justified; both the spontaneous and deliberate responses of healthy members of a social group usually conform to behavior patterns which, empirically, have proved most effective in promoting the group welfare. ${ }^{112}$ Many women, for example, absorb the notion that sexual experience is "dirty" or unpleasant, to be suffered or perhaps viewed in a different light only if marriage, betrothal, or "love" have preceded it. The woman's reaction of fear or disgust to coitus without these rituals encourages marriage. Other women may desire copulation to enrich relationships neither conjugal nor in anticipation of marriage. Pleasure, status, and other benefits may be sought through these alliances.113 And the use of sexuality for these ends, where the relationship is not of pathological origin nor the cause of

109. For a brief and interesting view on diverse attitudes toward sexual behswior and their effect on the operation of the law see KrNSEY, ET AI., op. cil. sipra nofe 99 , at 389-93 (1949). See notes 110, 150 infra.

110. "Except for the 15 per cent of the population which goes to college, most males actually accept pre-marital intercourse, and believe it to be a desirable part of normal human development. Even among those who publicly uphold the taboos against pre-marital relations, including legislators and the law enforcement officers who sporadically impose legal penalties upon non-marital activities, there are many who demonstrate through their own histories that they consider pre-marital and extra-marital intercourse acceptable and desirable. There is a not inconsiderable portion of the population which openly defends the value of such intercourse." KINSEY, ET AL. op. cit. supra note 99, at 599.

111. See Malinowski, The Group and the Indiridual in Fumetional Aralysis in Wuson \& Kolb, Soctological ANalysis 16S-72 (1049).

112. See Herskovits, Mian and His Work 289 (1948); Kreca \& Crutcafmed, op. cit. supra note 74 , at 386 .

113. "There are few women who fail to understand that their sexual charms can secure for them a 'position in life' which puts them above the need for indegendent essertion [se tirer a'affaire]. When calculating her chances in the struggle for existence, a girl puts on the credit side her personal attractions, the 'sex appeal' which will induce a man to work for her so that, forthwith or by degrees, she will secure money, status, leisure. Far from being ashamed of her sex (as some facile theorists would have us balieve), woman is extremely proud of her genital organs. They are the center of her power to give men incomparable pleasure. She would be amazed if they were neglected, undervalued, despised; and she counts on them to provide for her future, and perhaps lead her to unexpected heights." Guron, Sexula Fresnoss 198-9 (Paul's transl. 1939). Sce the discussion of the American "dating" system in MEan, MALE A:ND Feasnle 281-95 (1945). See also Waller. The Rating and Dating Comples in Newcoss \& Harmer, Readings in Soctal Pstrchology 338 (1947); Krnsey, et al., op. cif. sipro note 99, at 595. 
real hardship to others, may be an indirect aid to the smooth functioning of society. ${ }^{114}$ Certain limitations, however, hedge the woman's freedom to copulate; incest and prostitution are forbidden;115 fornication and adultery are often proscribed also. ${ }^{116}$ By penalizing the woman who consents to intercourse with anyone except her husband, these laws attempt to coerce her into withholding consent. But as evidence of the social desirability of allowing the woman to grant, as well as to withhold, consent to further her own purposes in the bargaining process, these fornication and adultery statutes are rarely enforced with vigor. ${ }^{117}$

The consent standard in our society does more than protect a significant item of social currency for women; it fosters, and is in turn bolstered by, a masculine pride in the exclusive possession of a sexual object.118 The consent of a woman to sexual intercourse awards the man a privilege of bodily access, a personal "prize" whose value is enhanced by sole ownership.110 A man may fear loss of the woman's sexual consent to a competitor. ${ }^{120}$ Against the potential seducer, the threatened lover is supposed to employ devices such as the manly art of wooing or recrimination of the woman to restore the relationship and maintain his masculine self-esteem. These devices, however, may do little to allay his anxiety. And he may not be able to resort to direct action against his competitor without a symbolic admission of impotence. Hence the fear and aggression aroused by the threat of deposal may be "displaced,"

114. Perhaps one of the more important, and unrecognized, values of non-marital sexual experience is the contribution it may make to successful sexual adjustment in marriage. See Ford \& Beach, Patterns of Sexual Beenavior 197 (1952). In general, there is no reason to expect pre-marital sexual relationships to be harmful to the social structure. Murdock, Soctal Structure 265.

115. E.g., 3 Conn. Gen. Stat., tit. 64, §8548 (1949) ; 9 Mass. Laws ANn., c. $272, \S 17$ (1933); N.Y. PENAL LAW $\S 1110$ (McKinney 1944).

116. E.g., 9 Mass. Laws Ann., c. $272, \S 18$ (1933); Penn. Stat. Ann., tit. $18, \S 4505$ (Purdon 1945).

117. See KInSEX, ET AL., op. cit. supra note 99, at 389-93; Ploscowe, SEX AND THE LAw 157 (1951).

118. "The demand that the girl shall bring with her into marriage with one man no memory of sexual relations with another is after all nothing but a logical consequence of the exclusive right of possession over a woman which is the essence of monogamy. . . ." 4 Freud, Collected Papers 217 (Riviere's transl. 1925).

119. GuYon, op cit. supra note 113 , at 200 .

120. The test of sexual competition offers a challenge to a man's self picture as a man, strong, independent, sexually potent. In the relationship with a woman, many men find satisfaction of this important goal of masculinity. See the brief summary of Alfred Adler's theory of the central importance of the masculinity goal in MULLAHY, OEdipus, Myth and CoMplex 122 (1948).

121. "Another common defense measure of the ego consists in displacing the object of an emotional attitude by another, thus saving the attitude. In displacement the tendency remains conscious and only its original goal remains unconscious. For example, a man 
acceptable target-the rapist. An additional reason for the man's condemnation of rape may be found in the threat to his status from a decrease in the "value" of his sexual "possession" which would result from forcible violation. Rape seems to arouse in most people a feeling of disgust, perhaps generated by the repressions surrounding aggressive sex $;^{122}$ and the disgust may spread to the body of the victim who is somehow thought to be contaminated by the experience. Words like "ravaged" and "despoiled" used to describe the rape victim reflect the notion of a stain attaching to the body of the girl. The man responds to this undercutting of his status as "possessor" of the girl with hostility toward the rapist; no other restitution device is available. The law of rape provides an orderly outlet for his vengeance.

Despite the prevalent taboo on aggressive sexuality, many "normal" men and women may unconsciously desire copulation coupled with brute force. The asocial need may be instinctual in origin ${ }^{123}$ or one facet of a general opposition to social restraints. ${ }^{124}$ Paradoxically, however, the asocial need may strengthen rather than undermine the taboo. When threatened by dangerous latent needs in their personalities, most people will resolve the conflict so as to preserve a socially acceptable self-picture. ${ }^{125}$ To accomplish this, the rational portion of the personality may deny the existence of the need with a vigor matching the strength of the dangerous desire. ${ }^{120}$ Such a person, as a con-

who feels hostile toward a benefactor because he is competing with him in business may direct his hostility toward another competitor to whom he owes nothing. . . . If a desire can not be gratified on account of external obstacles, even if it is not repressed, it may be exchanged for some other gratification." ALExanroER, op. cit. sipra note 88 , at 109, 110. See also Allport, G. W., Personality-A Psychologichl Internretation 184 (1937); MURphy, Personality 549 (1947).

122. "It has been stated before that repression is the iniantile ego's characteristic method of dealing with those instinctual demands which bring the child into confliet with its environment. Everything repressed has been originally forbidden by the parents or thwarted by the impersonal unchangeable conditions of the environment. A common example is the child's repression of coprophilic tendencies under the influence of parental disapproval. . . In the place of coprophilic tendencies, disgust appears." AuEsurroes, op. cit. supra note $8 S$, at 98 . It is suggested that disgust at aggressive sevual intercourse is another example of the same process.

123. See Murray, Explorations in Personality 135 (1938); Gardner, The Aggressive-Destrictive Impulses In the Sox Offonder, 34 Mfeus. HYc. 44 (1950).

124. See Saul, Easotional Maturity 110, 118-119, $138-9$ (1947). For a discussion of the sex offender as a product of hostility toward society, see Cushing, Psychopathology of Sezzual Delinquency, 11 J. Chmcal Psychopathology 49, 53 (1950); Scbire, The Sex Life of the Adolescent, $2 \mathrm{MED}$. J. of Australia 380 (1946).

125. "Indeed, so social are we that in order to look happily upon the self we must be sure that others accept and approve it." Afurphy, Persownlity 523 (1947). For a discussion of how such a picture is maintained in conflict situations, under threat of self devaluation from the unacceptable needs, see id. at 540, ot scq. See also Alersistan, op. cit. sitpra note 8 , at c. 5.

126. This is the mechanism of overcompensation or "reaction formation." See id. at 104. 
tinual reassertion of his or her own innocence, is likely to condemn vehemently all instances of rape. ${ }^{127}$ In other cases, the guilt aroused by the asocial need may produce a strong desire to punish the rapist as symbolic punishment of the self. ${ }^{128}$ Hence, among potential violators of cultural taboos, societies may find their most vigorous champions.

The interests of society, activated by the needs of its members, thus seem to demand punishment of a man solely because a woman subjectively opposes his sexual act. But such an approach to the law of rape would conflict with a vital community policy that allows individuals to rely, as a guide to their own conduct, on the behavior of others. Many areas of the law permit reliance upon the apparent meaning of another's words or actions. Otherwise, orderly relationships among individuals in our complex society wotld be severely hampered. ${ }^{20}$ Thus, where a woman demonstrates overt signs of acquiescence to sexual advances, consummation of the act should not jeopardize the man because of her unexpressed reservation of consent. ${ }^{130}$ The man is ignorant of the controlling fact which would brand his act rape-the woman's attitude of opposition. Here, the policy of protecting reliance on the behavior of others should prevail over the demand for protection of the woman's right to withhold consent. Similarly, if the woman has an ambivalent attitude and demonstrates willing behavior at the time of the act, fairness to the male suggests that he be adjudged innocent of wrongdoing.

\section{The Presumption of Non-Consent in Statutory Rape}

Most rapes do not occur contrary to the wishes of the participating girl. During the years 1945 and 1951 in Kings County, New York, 73\% of all rape indictments, where the accused was later convicted of rape or a lesser crime, were charges of statutory rape. ${ }^{131}$ In every case the basis for the accusa-

127. For a description of the mechanism of "projection" by which the recognition of asocial needs is prevented by attributing those needs to others, see $i d$. at 114 .

128. See Fenicher, op. cit. supra note 79, at 165.

129. "Although it is the unexpected behavior of our associates which most forcibly commands our attention, their anticipated actions are far more important in our daily lives. The average man expects his employer to pay him, his wife and children to respect and love him, and his friends to demonstrate a high degree of loyalty to him. In these and in countless other ways, he assumes a large measure of predictability in the actions of his associates." Wilson \& KolB, Socrological ANALxsis 155 (1949).

130. Gordan v. State, 32 Ala. App. 398, 26 So.2d 419 (1946). See also Taylor v. State, 249 Ala. 130, 30 So.2d 256 (1947).

131. These statistics are from the confidential files of the Probation Department of Kings County, New York (hereinafter referred to as Kings County Probation REPORTs). With the generous cooperation of Mr. Edmund Fitzgerald, Chief Probation Officer, and his department, the editors were able to make a complete survey of the very thorough reports prepared by department officers on every 1945 case of an indictment for forcible or statutory rape which resulted in a conviction on some charge. $A$ tabular summary of data gleaned from these reports is on file in the Yale Law Library. In New 
tion was intercourse with a girl under the age of eighteen. ${ }^{132}$ However, despite strong statutory penalties, ${ }^{133}$ this crime seemingly does not arouse the public clamor or official diligence that is characteristic of forcible rape cases. In fact, when confronted with the facts of a typical statutory rape case, few laymen would label the episode "rape."134 Yet two rationales may be enlisted to support the usual statutory rape law that sanctions the male who has intercourse with a willing underage girl, regardless of her previous sexual experience.

\section{Capacity and Comprehension: The Treasure Theory ${ }^{135}$}

The conclusive presumption of non-consent for underage girls is customarily rationalized in terms of the young girl's lack of capacity to understand the nature and implications of the sexual act. ${ }^{130}$ Here, as elsewhere in the law, ${ }^{150}$ her naive consent is without operative legal effect.

York City during the period from 1930-1939, 59\% of all convicted "sex ofienders" wiere charged with "statutory" rape. For the same period, $82, c$ of all rape convictions were for

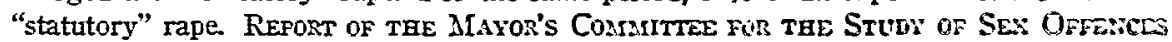
14, 45 (1939) (hereinafter cited MAAYoR's Refors). Rape is a felony, but only $20 \%$ of those indicted for statutory rape were later convicted of a felony; $66^{\circ}{ }^{\prime} c$ of those indieted for forcible rape were convicted of a felony. Id. Table VI at 47.

132. See N.Y. Penal Law $\$ 2010$ (McKinney 1944).

133. E.g., Cal. Penal Code $\$ 264$ (Deering 1949) (not more than fifty years); Itc. Retr. Stat., c 38, $\$ 490$ (1951) (one year to life).

134. This statement is based on answers to a questionnaire submitted to $165 \mathrm{New}$ Haven residents (hereinafter cited as QUestrownaInE). The sample included representatives of: the three main religious groups; educational levels ranging from less than a high school education to college graduate; both seses, married and unmarried; and various occupational groups, centered in the middle class. The respondents were members of clubs and other organizations, most of which were affiliated with the New Haven Y.M.C.A. A copy of the QUEsTionNarre and a tabulation of responses are on file in the Yale Law Library.

The QUESTIONNAIRE contained, in part, a series of hypothetical fact situstions, followed by questions directed at determining whether the respondent thought the act constituted rape and what sanctions should be invoked.

135. "Then weigh what loss your honor may sustain If with too credent ear you list his songs,

Or lose your heart, or your chaste treasure open

To his unmastered importunity." Shafespease, Hasreser, Act I, scene iii, 1. 29.

136. "The victim is without capacity and discretion to have a proper conception of the character of the offense being committed against her person, or to comprehend its consequences fully, or perhaps to possess the strength of will to resist the influence and importunities of the ravisher. That is actually so of an idiot and presumptively so of a child." Golden v. Commonwealth, 289 Ky. 379, 385, 158 S.W.2d 967, 969 (1942). Scc also, e.g., Fields v. State, 203 Ark. 1046, 1048, 159 S.W.2d 745, 747 (1942); State v. Adlins, 106 W. Va $658,663,146$ S.E. 732,734 (1929).

137. The contracts of children, e.g., are voidable at law. 1 Conser, Cosinucrs $\$ 6$ (1950) ; 1 Williston, Contracts $\$ 226$ (rev. ed. 1936). Marriages by children under a prescribed age may be annulled by the minor. MADDEN, Dosirstic ReLitro:ss $\S 13$ (1931). 
A popular conception of a girl's sexual indulgence or virginity as a "thing" of social, economic, and personal value ${ }^{138}$ explains, in part, the law's concern with her capacity to "understand."130 An "unwise" disposition of a girl's sexual "treasure," it is thought, harms both her and the social structure which anticipates certain patterned uses. Hence, the law of statutory rape must intervene to prevent what is predicted will be an unwise disposition. And prevention is sought not by penalizing the "naive" girl but by sanctioning the male, who is always assumed to be responsible for the occurrence. ${ }^{140}$

The assumption that age alone will bring an "understanding" of the sexual act is of doubtful validity. Both actual sexual experience and learning from the cultural group to which the girl belongs will determine her level of comprehension. The sexually experienced fifteen year old may be more acutely aware of the implications of sexual intercourse than her sheltered cousin who is above the age of consent. And a girl who belongs to a group whose members regularly indulge in sexual intercourse at an early age, is likely to accutire rapidly an insight into the rewards and penalties her group will award to different sexual choices. Thus, "wisdom" in the disposition of her sexual favors is likely at an early age, although her behavior may not be "wise" when judged by the moral codes of other groups. Moreover, when a girl's actual comprehension contradicts the law's generalization, the facts may belie the assumption that the male is always responsible for the act. It is difficult to see the justice of a rape sanction against a male, perhaps himself young and naive, who responds, for example, to an underage prostitute's advances.

\section{The Psycho-medical Argument}

A further argument for a criminal sanction based solely upon the girl's age is grounded on the fear that young girls are likely to suffer psychic or physical injury from the sex act. If the girl has not yet reached puberty, there may be cause to expect such harmful effects. ${ }^{141}$ At this time the girl

138. See Guyon, The Ethics of Sexual Acts 200 et seq. (Flugel's transl، 1948).

139. A popular myth which disavows the coexistence of youth and sexuality also supports the law. The young, it is felt, are "pure" and "innocent," and sexual experience is sullying and worldly. Thus, instances of sexuality in children are often harshly suppressed. See, e.g., Huschka, The Incidence and Character Of Masturbation Thrcats In a Group of Problem Children in Tomkins, Contearporary Psychopathology 49-62 (1947).

140. Cf. James v. State, 246 Ala. 617, 21 So.2d 841 (1945) ("the protection of the innocent and helpless") ; Martin v. State, 17 Ala. App. 73, 81 So. 851 (1919) ("the protection of young females by absolutely prohibiting sexual intercourse with them"); Elkins v. State, 157 Tenn. 548, 72 S.W.2d 550 (1933) ("enacted for the purpose of protecting from seduction innocent and immature girls, protecting them from the wiles of men of greater experience in sexual affairs").

141. Relatively little is known about differences in the psychic effects of pre-pubertal and post-pubertal sexual experience. Freud has mentioned the possibility of a link bc- 
probably lacks an emotional understanding of the feminine role in sexual intercourse. The girl's immature orientation may cause her to distort the emotional significance of the act, and the lingering effects of the distortion may jeopardize her later sexual adjustment. ${ }^{15: 2}$ Furthermore, physical injury may result from the penetration of immature genitalia. ${ }^{143}$

Coitus occurring after puberty, willingly undertaken by the girl, and representing the fulfillment of a normal physiological need, probably cannot in itself harm her. ${ }^{144}$ With the advent of puberty the normal girl undergoes a marked change in sexual development and concurrent emotional orientation. She assumes the feminine role in both her general behavior and sexual desires. ${ }^{145}$ At this stage the likelihood of psychic harm appears to be a function of the cultural inhibitions inculcated in the girl rather than of her years. ${ }^{146}$ Where the behavior is non-conformist, it may cause feelings of alienation from the group or of guilt which impair her later wellbeing. ${ }^{147}$ But almost all cases of statutory rape which reach police and courts involve persons from a low socio-economic group. ${ }^{145}$ This same

tween neurosis and early sesual experience. 1 Freud. Collected Papgrs 150 (Riviere's transl. 1924). Many young girls, discovering the difference between male and female genitalia, envy the male's superior endowment and may unconscivusly desire to ca trat: him. When this desire is in ascendancy, coitus may represent castration. This lo wic orientation toward coitus may endure to jeopardize later sexual adjustment. Sie + Fnccu, Collected Papers 231 (Riviere's transl. 1925).

142. Ibid.

143. See Scammon, Dezclopmental Anatomy in Morris' Husas Aisuroury 41 (10th ed. 1942).

144. Interview with a psychiatrist, whose name is vithheld by ruquest.

145. See Freud, The Transformations of Pulcrty in Tue Busic Wirurats of SigMIUND FREUd 60429 (Erill's transl. Mod. Lib. ed. 1938).

146. Anthropological studies of contemporary primitive sucieties suggest this conclusion. "Lifting the taboo [against pre-marital coitus] lessens the burden of guilt accompanying such behavior, and thereby presumably reduces the incidence of psychoneuroses. ... [A]dolescents are enabled to establish the normal heterosexusl habits that are adaptive in married life, instead of being driven through anxiety into less preferred patterns of sexual behavior. Perversions ... are unknown or exceedingly rare among more lenient peoples [than Americans]." Murdock, A Comparative Anthropological Approdeh, $36 \mathrm{~J}$. Soc. HYGIENE 133, 137 (1950).

147. "The middle-class adolescent is punished for physical aggression and for physical sexual relations; the lower-class adolescent is frequently rewarded, both socially and organically, for these same behaviors. The degree of anxiety, guilt or frustration attached to these behaviors, therefore, is entirely different in the two cases." Allison Davis,

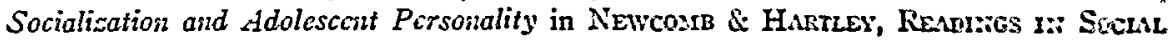
Psychology 148 (1947) (italics omitted). For a discussion of the origin and operation of guilt feelings in anxiety disturbances, see Alexandes, Fundonsentals of PsycroANALr'sIs 118 et seq. (1948). For the view that "feelings of alienation" contribute to the "soil out of which a neurosis may grow," see Horney, New Ways In Psychoasinursis 172 (1939).

148. Kungs County Probatron Reports. See Mlayor's Refort 12, 72 at seq.; Webb, Delinquency In the Mraking, 29 J. Scc. Hyglese 502 (1943). 
cultural sub-group indulges in heterosexual relations at a comparatively early age. ${ }^{149}$ And this group apparently lacks a strong taboo against physical outlet for emotions. ${ }^{150}$ Intercourse with underage girls occurs, of course, in higher echelons of our society, which have different moral precepts. ${ }^{151}$ But the fact that these episodes go unreported raises serious doubts as to the preventive value of statutory rape sanctions among these groups. In addition to cultural taboos, the impact upon the personality of a given incident is reduced by the individual's previous exposure to similar events. ${ }^{162}$ Since complaining witnesses in statutory rape cases typically have had considerable sexual experience, ${ }^{163}$ there should be slight danger of psychic injury.

Some may argue that the purpose of a statutory rape sanction is to prevent pregnancy among young girls. But this purpose cannot be inferred from statutes or cases since no distinction in culpability is made between men who used contraceptives and those who did not. In essence, the fear of this form of "harm" to the girl is contained in the fear that the young girl lacks comprehension of the implications of coitus. Yet, today, an underage girl, particularly if she is sexually experienced, is likely to be aware of the danger of pregnancy, and familar with the methods and desirability of preventing it.

\section{A Suggested Approach}

The presumption that a young girl lacks the capacity to comprehend the nature and implications of sexual intercourse should be rebuttable. The defendant should be permitted to introduce evidence which tends to show that the complaining witness, in fact, understood the significance of the act in question. If the accused can prove such comprehension affirmatively, the girl's

149. Nearly half the males in the lower educational group (which roughly corrcsponds to socio-economic level) actively engage in heterosexual intercourse between adolescence and the age of fifteen, as compared with only ten per cent of future college boys. In later teens, the figure is $85 \%$ of grade school group and $75 \%$ of high school group. KINSEY, ET AL, op. cit. sitpra note 99, at 347. "The pre-marital coital picture for the grade school and high school groups are much alike. They both differ from the college group in starting their intercourse at a much earlier age-in many cases in preadolescence, and in a large number of cases coincidentally with the onset of adolescence. Within two or three years after the onset of adolescence nearly all those who will ever be involved have started heterosexual relations." Id. at 349. When juxtaposed with the overwhelmingly high proportion of early heterosexual outlet with "companions" rather than prostitutes, $i d$. at 376 , it seems clear that the figures should not be restricted to males.

150. See Allison Davis, supra note 147, at 139-50. "Like physical aggression, sexual relationships and motivation are far more direct and uninhibited in lower-class adolescents. The most striking departure from the usual middle-class motivation is that, in much lower-class life, sexual drives and behavior in children are not regarded as inherently taboo and evil." Id. at 148.

151. Ibid.

152. See Fenichet, Psychoanalytic Theory of Neurosis 132-3 (1945).

153. Kings County Probation Reports; Interview 4. 
consent should have the same legal effect as that of her older sister. Admittedly, a girl's experiences, which determine her sexual sophistication, would be many, varied, and subtle. So the trial court must have wide discretion to pass on the relevancy of any given item of evidence to the central issue of the girl's actual understanding. Evidence of previous sexual contact of any sort with other men would, of course, be admissible. Events which have a less direct bearing on her understanding should be admissible at the court's discretion. This approach to the issue of "capacity" is similar to that in statutory rape cases where the girl is alleged to be mentally impaired. Her capacity to grant operative consent is a question of fact for the jury. ${ }^{15 / 2}$

The rebuttable presumption would continue to protect the "pure" from defilement and prevent the "naive" girl from making an "unwise" disposition. But the law would no longer punish the man who copulates with a girl fully capable of understanding the significance of her participation. ${ }^{105}$ And there is no automatic sanction attaching to a wrong guess alout the age of a girl who is obviously sexually sophisticated. ${ }^{150}$ Moreover, the rape sanction could no longer be invoked by outraged parents to assuage their injured sensibilities when, in fact, there was little possibility of injury to the girl.

The "chastity" and "good reputation" tests employed by some states seem inadequate to gauge a young girl's capacity to consent. A single act of coitus will render a girl unchaste, yet its effect on her ability to understand the significance of the sex act may be negligible. And the "good reputation" test invites reliance on community gossip, while excluding evidence of the girl's actual experiences.

154. "Whether the woman possessed mental capacity sufficient to give legal consent must, saving in exceptional cases, remain a question of fact for the jury. It need but be said that legal consent presupposes an intelligence capable of understanding the sct, its nature and possible consequences. This degree of intelligence may exist with an imgaircd or weakened intellect or it may not." People v. Griffin, 117 Cal. 583, 585, 49 Fac 711, 712 (1S97). See Hacker v. State, 73 Okla. Crim. 119, 118 P.2d 408 (1941); Commonwealth v. Stephens, 143 Penn. Super. 394, 17 A.2d 919 (1941). Sec also Wilson v. Commonwealth, $290 \mathrm{Ky} .223,227,160$ S.W.2d 649, 651 (1942) (that a woman without sufficient mind to contract may consent to intercourse).

155. The following case is taken from Kuxas Cousty Prod.mon Reforss (anonymity of the parties is preserved): a young boy, apparently from a lower-middle class home, with a clean police record, stopped his car on a street corner one evening for a traffic light. A girl of about 17 stood on the corner. She customarily slept with strange men in return for a place to spend the night; if she found no one she slept in hallways. She approached the boy's car and offered to have sexual relations with him in return for spending the night in his car. He assented and she got into the car. They drove to a vacant lot, stopped the car, and performed an act of sexual intercourse in the rear seat of the car. A passerby noticed the car and notified the police. On the arrival of the patrol car, the pair fled. They were caught by the police, arrested, and the boy charged with statutory rape.

156. It has been suggested, though never judicially accepted, that if a "reasonable man" would have thought the girl to be of legal age and she was active in soliciting the 
In the light of the foregoing, the following is submitted as a substitute for existing laws of statutory rape:

Any man who has sexual intercourse with a girl under the age of seventeen years shall be guilty of rape. But if the girl is fourteen years or over and comprehends the nature and implications of the sex act, then her consent to the act in question shall be an absolute defense. The burden of proving the girl's comprehension shall be on the accused and relevant evidence of her previous experience in, or knowledge of, sexual matters, from whatever source such experience or knowledge has been obtained, shall be admissible for this purpose.

\section{ENFORCEMENT ${ }^{157}$}

Prosecutors and courts have wide discretionary powers when enforcing the laws of forcible and statutory rape. ${ }^{158}$ And both the diligence of prosect1tion and the severity of sentences manifest an extreme lack of uniformity. ${ }^{150}$ This flexibility in the enforcement process undoubtedly results from the wide range of factual situations encompassed by the laws and the varying public responses toward specific instances of rape. ${ }^{160} \mathrm{~A}$ violent night-time attack by a stranger will outrage the public; vigorous efforts to apprehend and convict are almost certain to follow, as is a heavy sentence. The response of the enforcement process is less predictable in the forcible rape case where the parties were previously acquainted, perhaps with some emotional attachment between them. ${ }^{161}$ And many people are reluctant to penalize the man when they believe he was "led on" by the woman, even though she resisted the actual penetration. ${ }^{162}$ Finally, the fully consensual sexual episode involving an underage girl arouses the least reaction. Busy public attorneys may prosecute grudgingly and judges typically impose mild penalties. ${ }^{163}$

\section{The Prosecutor's Discretion}

The prosecutor's discretion with respect to the acceptance of the accused's guilty plea to a lesser offense is of controlling importance in the ultimate

act of intercourse, the man should be acquitted. INTERviEw 6, 30; PLoscowe, SEX AND THE LAW 184-5, 194 (1951).

157. No attempt has been made here to explore the purposes (e.g., rehabilitation, deterrence, isolation, etc.) and effects of penal sanctions or the methods by which they are chosen. For an investigation of this problem, and a suggested approach, sce UviLLER, The Imposition of Sancrions (unpublished ms. in the Yale Law Library, 1952). Sce also Sutherland, Prinicples of Criminology cc. 18, 19 (4th ed. 1947).

158. InTERview passim. See Charts I, II, and III, AppENDIx, infra.

159. See charts in APPENDIX, infra.

160. Questionnaire. Some flexibility in the application of criminal sanctions is desirable to meet the individual needs of the offender involved. See Saleilles, Thic Individualization of Punishment, 4 MIODERN CRIM. Scr. SER. 8-10 (1911).

161. Kings County Probation Reports.

162. QUesTIONNAIRE.

163. See Chart I in Appendix, infra. 
disposition of a rape accusation. ${ }^{164}$ In Kings County, New York, in 1945, half the forcible rape indictments were disposed of by such pleas. ${ }^{165}$ Seven out of eight statutory rape cases were handled the same way. ${ }^{160} \mathrm{~A}$ certain but minor punishment often seems a better bet to the defendant than the possibility of a severe one. Moreover, the prosecutor is not obliged to ask the grand jury for an indictment if he believes the complaint to be groundless. ${ }^{167}$ Thus, in the vast majority of cases, the rape charge may be "adjudicated" before it ever reaches a court.

Where justice is dispensed over the prosecutor's desk, prejudice and whim or impartial and thorough thought may guide the disposition of the case. The personality and intelligence of the man who makes the decision, as well as his methods of investigation, will determine the manner in which he decides and the wisdom of his ultimate decision. ${ }^{168}$ But all prosecutors generally develop "rules of thumb" which they believe adequate to uncover the truth from the narratives and appearances of the parties. ${ }^{160}$ Such factors as the race of the parties, their economic or social standing, the prior criminal record of the defendant, or the reputation of the girl may influence them strongly. ${ }^{170}$ Because of the heavy demands for his attention, a prosecutor may decide to prosecute a case of forcible rape on the basis of the availability of tangible evidence of a physical struggle.171 Furthermore, since most public prosecutors are elected officials and may have political ambitions, many are likely to be infuenced by the "scandal" quality of an accusation..72 The prominent position given to forcible rape charges by many newspapers may excite a public demand for retribution, which the prosecutor can ill afford to ignore. Unfortunately, most scientific tests are rarely used. The lie detector is a piece of equipment typically ignored by public attorneys. ${ }^{173}$ And most prosecutors' offices do not submit the parties, particularly the complaining witness, to psychiatric examination. ${ }^{174}$

164. See Prelnimany Report of the Subcomantree on Sex Crunes of the CaltForNla Legislature 37 (1950); INTERTIEW 3, 11, 15. In New York City during the period 1930-39, 87\% of all convicted sex offenders entered guilty pleas. MsYor's Refost 14.

165. Krngs County Probation Reports.

166. Ibid.

167. INTERVIEW 2 .

168. Id. at $22,23,32,33$.

169. Id. at 18; communication to the YALE LAw JourNaL from Mr. Abraham S. Ullman, State's Att'y, New Haven, Conn., dated April 2s, 1952, in Yale Law Library.

170. Ibid; INTERVIEW 15.

171. INTERVIEW 11.

172. Communication, supra note 169.

173. INTERvIEw 17. Communication to the Yale LAw Journal from Mr. Abraham S. Ullman, State's Attorney, New Haven, Conn., dated November 8, 1952, in Yale Law Library.

174. Ibid. 


\section{The Sentencing Judge's Discretion}

Statutes allow the judge the widest range of sentences both for forcible and statutory rape. Commonly, a judge has discretion to suspend sentence, suspend the execution of sentence, jail a convicted man for one to fifty years, or give him a life sentence. ${ }^{175}$ In some southern states, a death sentence mat also be pronounced. ${ }^{176}$ It is notable, however, that the majority of statutory rape defendants, who are convicted on some offense, receive suspended sentences; virtually none receives a prison sentence greater than one year. ${ }^{177}$

Judges appear to take advantage of the range of available punishments. ${ }^{178}$ The choice of punishment is probably based largely on the judge's courtroom observation of the parties, the circumstances of the crime, and the prior record of the defendant. In some jurisdictions, however, a special department of trained investigators prepares a detailed report on the background and personality of the guilty man to aid the judge in imposing an appropriate sentence. ${ }^{179}$ Such an aid to the sentencing seems in the best interests of both the convicted party and the society which has produced him.

\section{CONCLUSION}

The role of sexual energy in our society justifies the consent standard in forcible rape. Yet the necessity of relying on the woman's behavior to determine her subjective attitude may lead to serious injustices. Evidence of a woman's behavior will not always portray accurately her attitude toward the sex act. And the actions of a woman whose attitude is ambivalent may leave signs of "resistance" to support a subsequent accusation. To learn the woman's attitude more precisely, enforcement officers should turn to psychiatric counsel and other scientific fact-finding aids. These procedures are more likely to uncover conscious or unconscious distortions in the woman's report than a prosecutor's intuitive judgment.

The crime of statutory rape is unsupportable in its present form. Neither the policies underlying the law nor public sentiment warrants the imposition of rape penalties solely because of the girl's youth. By making the presumption of the underage girl's incapacity rebuttal, the law would continue to protect the "naive." But although legally underage, the girl who is past puberty and sexually sophisticated would be capable of granting operative consent to sexual intercourse.

175. See Holman, Statutory Rape, Chart I (unpublished ms. in Yale Law Library, 1952).

176. E.g., Ala. Code tit. 14, $\$ 395$ (1940) ; Fla. Stat. Anv. $\$ 794.01$ (1943); Miss. Code ANN. $\$ 2358$ (1942). From 1930 to 1948, an average of seventeen persons were executed for rape annually. Ploscowe, Sex and the Law 165 (1951).

177. See Chart I in APPENoIX, infra; MAyor's Report 15.

178. See, e.g., Chart $I$ in Appendix, infra.

179. See note 131 supra. 
APPENDIX

Maximum Sentences, All Cases, Krngs County, N. Y., 1945广

Chart I

Forcible Rape Statutory Rape

Indictments Indietments

Suspended Sentence or Suspended

Execution of Sentence

6 months or less

6 months to 1 year

1 to 3 years

3 to 5 years

5 to 10 years

Over 10 years

County Penitentiary

State Prison

Vocational Institution

$\$ 50$. Fine

Does Not Appear

26

4

1

1

0

0

0

2

1

0

0

2

62

Disposition Of Rape Indictments, Kings County, N.Y., 1945†

FoRCIBLE RAPE INDICTMENTS

Convicted of

Forcible Rape

Statutory Rape

2d Degree Assault

Attempted 2d Degree Assault

3d Degree Assault

Endangering Life or Health

of Child (misdemeanor)

Chast II

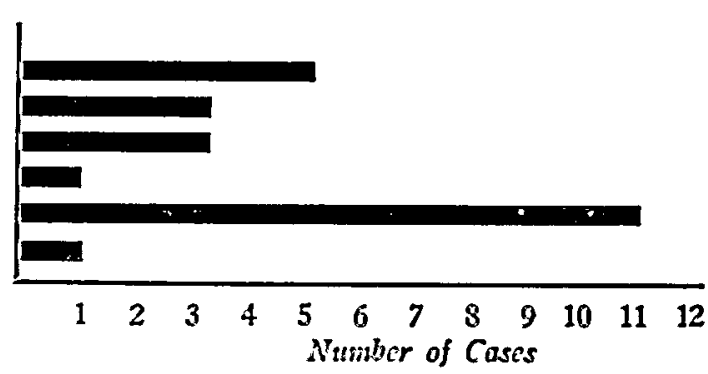

Statutory RApe IndictMents

Convicted of

Chart III

Statutory Rape

Attempted Statutory Rape

2d Degree Assault

3d Degree Assault

Endangering Life or Health

of Child (misdemeanor)

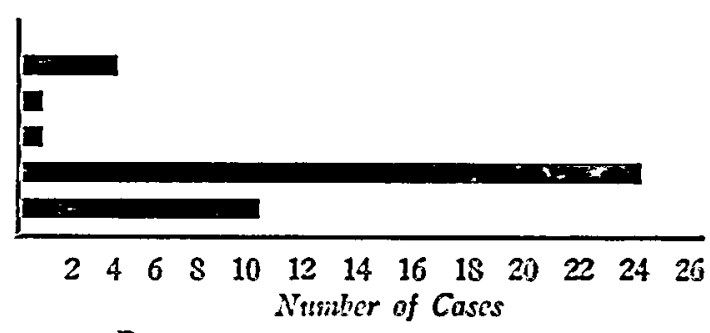

iData from Krngs County Probation Reports.

"Includes cases disposed of by plea ( 51 cases), by verdict ( 6 cases), and by plea entered during trial (5 cases). 